\title{
Tolerance of Four Dry Bean Market Classes to Pre-Emergence Applications of Sulfentrazone
}

\author{
Allison N. Taziar ${ }^{1}$, Nader Soltani ${ }^{1}$, Christy Shropshire ${ }^{1}$, Darren E. Robinson ${ }^{1}$, Mitch Long ${ }^{2}$, \\ Chris L. Gillard1, Peter H. Sikkema1
}

${ }^{1}$ University of Guelph Ridgetown Campus, Ridgetown, Canada

${ }^{2}$ FMC Corporation, Saskatoon, Canada

Email: soltanin@uoguelph.ca

How to cite this paper: Taziar, A.N., Soltani, N., Shropshire, C., Robinson, D.E., Long, M., Gillard, C.L. and Sikkema, P.H. (2016) Tolerance of Four Dry Bean Market Classes to Pre-Emergence Applications of Sulfentrazone. American Journal of Plant Sciences, 7 , 2248-2256.

http://dx.doi.org/10.4236/ajps.2016.715198

Received: October 8, 2016

Accepted: November 7, 2016

Published: November 10, 2016

Copyright $\odot 2016$ by authors and Scientific Research Publishing Inc. This work is licensed under the Creative Commons Attribution International License (CC BY 4.0).

http://creativecommons.org/licenses/by/4.0/

\begin{abstract}
Ontario dry bean growers are currently limited to ALS inhibitor herbicides for soilapplied broadleaf weed control; therefore another mode of action is needed. Sulfentrazone is a PPO inhibitor herbicide that has activity on some annual grass and broadleaf weed species. Four field trials were conducted over two years $(2014,2015)$ to determine the tolerance of four commonly grown dry bean market classes (adzuki, kidney, small red Mexican and white bean) to PRE applications of sulfentrazone at 140, 210, 280 and $420 \mathrm{~g} \cdot \mathrm{ai} \cdot \mathrm{ha}^{-1}$. Crop injury, plant height, plant density, shoot biomass, seed moisture content and yield were examined. Sulfentrazone (420 g.ai $\cdot \mathrm{ha}^{-1}$ ) caused up to $74 \%, 22 \%, 30 \%$, and $57 \%$ injury in adzuki, kidney, small red Mexican and white bean, respectively. Plant density, height and yield were not reduced for kidney or small red Mexican bean. Sulfentrazone (420 g.ai.ha ${ }^{-1}$ ) reduced white bean plant density, height and yield by $28 \%, 29 \%$ and $29 \%$, respectively; and reduced adzuki bean plant density, height and yield by $51 \%, 34 \%$ and $57 \%$, respectively. Overall, kidney and small red Mexican bean were the most tolerant to sulfentrazone, followed by white bean, and then adzuki. This study determined sulfentrazone applied PRE is safe for Ontario kidney bean and small red Mexican bean crops.
\end{abstract}

\section{Keywords}

Adzuki Bean, Kidney Bean, Small Red Mexican Bean, White Bean, Injury, Density, Height, Seed Moisture Content, Yield

\section{Introduction}

Dry beans (Phaseolus vulgaris L.) are an important crop for southwestern Ontario. In 2014, over 50,000 ha of white and coloured dry beans were seeded in Ontario, produc- 
ing 125,000 T with an approximate value of $\$ 111,000,000$ [1]. Popular market classes of dry beans grown in Ontario include black, cranberry, kidney, white (navy), otebo, small red Mexican, and adzuki (Vigna angularis (Willd) Ohwi \& Ohashi). Weeds can significantly reduce dry bean yield as weeds can outcompete the beans for essential resources [2] [3] [4]. Studies have found 70\% yield loss can occur in dry beans from competition with weeds [5].

Only two soil-applied broadleaf herbicides are registered for Ontario dry beansimazethapyr and halosulfuron. Both are group 2, ALS inhibitor herbicides. As there are more than ten documented weed species with group 2 resistance in Ontario [6], another mode of action is needed for weed management in dry beans. Sulfentrazone is a soil-applied, protoporphyrinogen oxidase IX (PPO) inhibitor herbicide that provides residual control of many broadleaf weeds and some grasses. Sulfentrazone causes an excess of protoporphyrinogen IX in the chloroplast, which then leaks into the cytoplasm and is converted to protoporphyrin IX. As weeds emerge from the soil, the protoporphyrin IX reacts with light to produce $\mathrm{O}^{+}$, which peroxidizes cell membranes causing cellular leakage. It controls weed species such as Amaranthus retroflexus L. (redroot pigweed), Amaranthus tuberculatus var. rudis (waterhemp), Chenopodium album L. (common lambsquarters), Digitaria spp. (crabgrass), Panicum spp. and $S e$ taria faberii L. (giant foxtail) [7] [8] [9]. Sulfentrazone is registered Canada-wide for pre-emergence (PRE) use in chickpea (Cicer arientinum L.), soybean (Glycine max L.), sunflower (Helianthus annuus L.), and field pea (Pisum sativum L.). There is little information on the response of dry bean market classes to PRE applications of sulfentrazone in Ontario.

The objective of this research was to determine the tolerance of four market classes of dry bean to PRE applications of sulfentrazone at 140, 210, 280 and 420 g.ai.ha ${ }^{-1}$, representing $1 \times, 1.5 \times, 2 \times$ and $3 \times$ registered rate in Ontario.

\section{Materials and Methods}

\subsection{Experimental Design}

Four field trials were conducted over a two-year period $(2014,2015)$ at the Huron Research Station near Exeter, Ontario and University of Guelph Ridgetown Campus in Ridgetown, Ontario, Canada. In 2014, the soil in Ridgetown was a loam with $40 \%$ sand, $35 \%$ silt and $25 \%$ clay, organic matter content of $7.1 \%$ and $\mathrm{pH}$ of 6.6 . In 2015 , Ridgetown soil was a sandy clay loam with $53 \%$ sand, $27 \%$ silt, $20 \%$ clay, organic matter content of $5.3 \%$ and $\mathrm{pH}$ of 7.0. Exeter Site A was a silty clay loam with $18 \%, 46 \%$, and $36 \%$ sand, silt and clay, respectively, with an organic matter content of $4.7 \%$ and $\mathrm{pH}$ of 7.5. Site B was a loam with $35 \%$ sand, $43 \%$ silt, $22 \%$ clay, organic matter content of $3.6 \%$ and $\mathrm{pH}$ of 7.6. Seedbeds were prepared by moldboard ploughing in the fall and two passes with a cultivator with rolling basket harrows in the spring.

The experiments were arranged in split-plot design with 4 replicates. Main plots were herbicide rate and subplots were four commonly grown dry bean market classes (adzuki, kidney, small red Mexican and white bean). Plots were $6 \mathrm{~m}$ wide ( 2 rows of each 
market class spaced $0.75 \mathrm{~m}$ apart) by $8 \mathrm{~m}$ long in Ridgetown and $3 \mathrm{~m}$ ( 1 row of each market class spaced $0.75 \mathrm{~m}$ apart) by $10 \mathrm{~m}$ long in Exeter. Dry beans were seeded to a depth of 4 to $5 \mathrm{~cm}$ in late May to early June. Different discs were used to adjust the seeding population depending on market class and location as per provincial agronomic recommendations. In Ridgetown, adzuki, small red Mexican and white bean were seeded at a rate of 232,900 seeds $\cdot \mathrm{ha}^{-1}$ and kidney beans were seeded at 175,500 seeds $\cdot \mathrm{ha}^{-1}$. At the Exeter locations, adzuki bean was seeded at 272,000 seeds.ha ${ }^{-1}$, white bean was seeded at 254,000 seeds.ha ${ }^{-1}$, and kidney and small red Mexican beans were seeded at 212,000 seeds.ha ${ }^{-1}$. Herbicide treatments included an untreated control and four rates of sulfentrazone $\left(140,210,280\right.$ and $\left.420 \mathrm{~g} \cdot \mathrm{ai}^{\cdot h \mathrm{ha}^{-1}}\right)$. Herbicides were applied using a $\mathrm{CO}_{2}$ pressurized backpack sprayer and a $1.0 \mathrm{~m}$ handheld boom with three ULD 110-02 nozzles (Hypro, New Brighton, MN) spaced $0.5 \mathrm{~m}$ apart, calibrated to deliver $200 \mathrm{~L} \cdot \mathrm{ha}^{-1}$ at $240 \mathrm{kPa}$. Plots were maintained weed-free by hand-hoeing for the entire growing season to eliminate the confounding factor of weed interference.

Crop injury was visually assessed at $1,2,3,4,6$, and 8 weeks after crop emergence (WAE). At $3 \mathrm{WAE}$, plant density was determined by counting the number of plants in a metre of row for each market class. A metre of row for each market class was then harvested at ground level, placed in separate paper bags, and dried in a kiln. Once dry, the plants were weighed to determine dry shoot weight. At $6 \mathrm{WAE}, 10$ plants from each treatment were randomly selected for height measurement, and their heights were averaged for each market class. Seed moisture content and yield-adjusted to 15\% moisture for adzuki and 18\% moisture for kidney, small red Mexican and white bean-were determined at maturity.

\subsection{Statistical Analysis}

All analyses were conducted in SAS version 9.4 (SAS Institute Inc., NC). Fixed effects for the analysis included sulfentrazone rate, bean market class, and their interaction; and their significance was determined with the F-test. Random effects included environment (year-location combination), block nested within environment, rate by environment interaction, market class by environment interaction, and rate by market class by environment interaction. Their significance was determined with the Z-test. The assumptions of normality and homogeneity of the residuals were tested with the UNIVARIATE procedure under various transformations of the data. The transformation that produced the highest Shapiro-Wilk statistic for each data set was selected for the analysis. Data were then subjected to analysis of variance using the MIXED procedure and Fisher's Protected LSD test with a significance level of 0.05. Data were transformed back to the original scale for presentation.

\section{Results and Discussions}

Statistical analyses determined that the market class by environment interaction was significant for most data sets. This is likely due to the beans responding to the different soil types and weather conditions. However, there were no significant environment, 
rate by environment interaction, or rate by market class by environment interaction effects, and so data were pooled for the analysis. Analyses revealed that sulfentrazone rate was significant for all assessments, and bean market class was significant for injury at 2 , 3, 4, 6 and 8 WAE, plant density, height, shoot dry weight, seed moisture content and yield (Table 1). Rate by market class interaction was significant for injury 3, 4, 6 and 8 WAE, plant density, height, and yield (Table 1).

\subsection{Crop Injury}

Crop injury symptoms in this study included leaf crinkling and cupping, reduced growth, and reduced plant stand. At 1 WAE, sulfentrazone at 140, 210, 280, and 420 g.ai $\cdot \mathrm{ha}^{-1}$ caused $2 \%, 4 \%, 11 \%$, and $35 \%$ injury, respectively (Table 1 ). None of the herbicide treatments were equivalent to the control. At $2 \mathrm{WAE}$, the level of injury caused by sulfentrazone at 140,210, 280, and $420 \mathrm{~g} \cdot \mathrm{ai} \cdot \mathrm{ha}^{-1}$ was similar to $1 \mathrm{WAE}$ with $1 \%, 5 \%$, $10 \%$, and $29 \%$ injury, respectively. Soltani et al. [10] reported a similar level of injury of

Table 1. Mean values of main effects and their interaction for crop injury, plant density, shoot dry weight, plant height, seed moisture content and yield of dry bean treated with sulfentrazone PRE at Ridgetown and Exeter, Ontario in 2014 and 2015 . Means followed by the same letter within a column are not significantly different according to Fisher's Protected LSD at $\mathrm{P}<0.05^{\mathrm{a}}$.

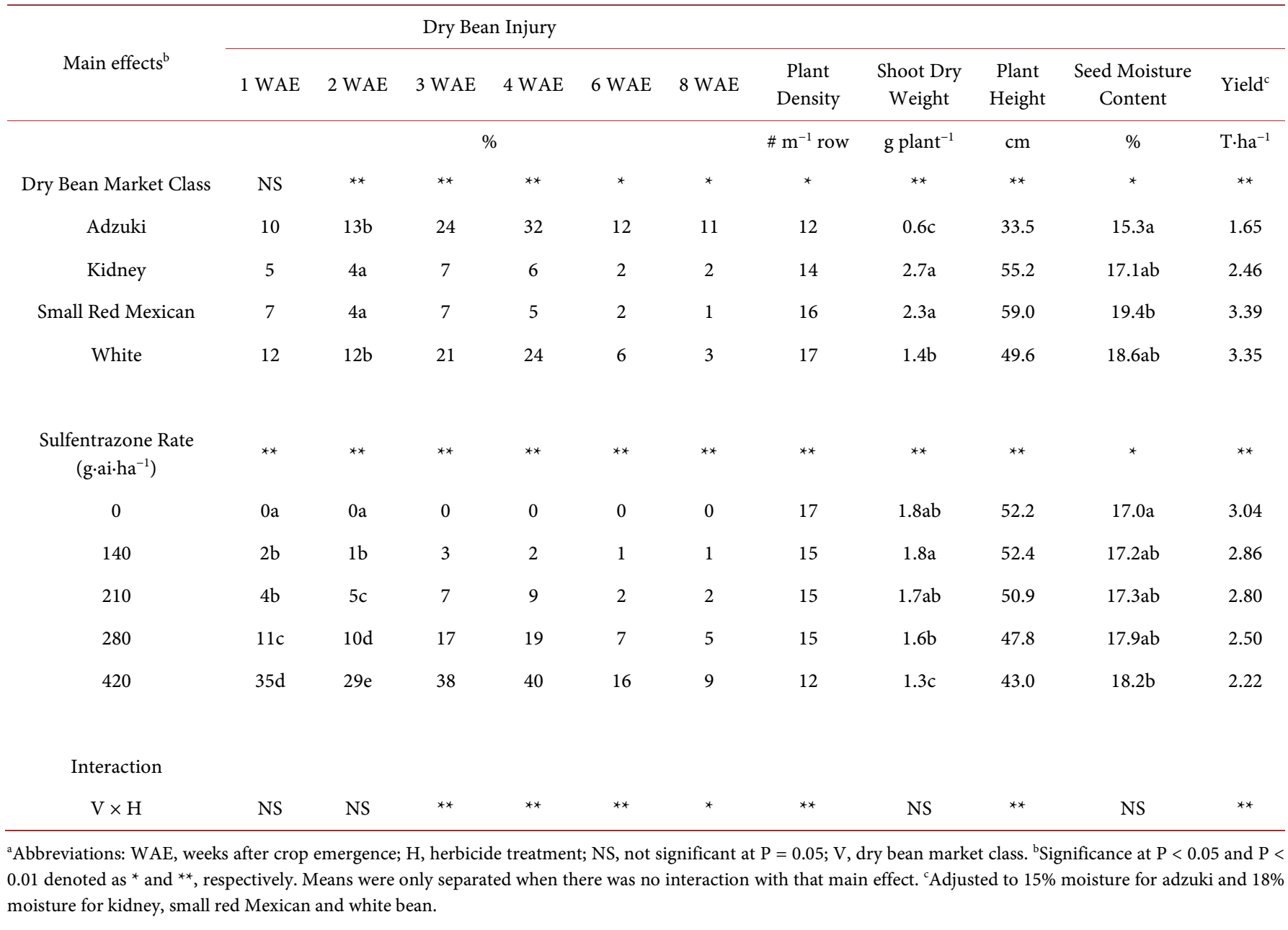


$11 \%$ in dry bean treated with $280 \mathrm{~g} \cdot a \mathrm{i} \cdot \mathrm{ha}^{-1}$ sulfentrazone at $2 \mathrm{WAE}$, but Hekmat et al. [11] found sulfentrazone at $420 \mathrm{~g} \cdot \mathrm{ai} \cdot \mathrm{ha}^{-1}$ only caused an average of $12 \%$ injury across eight market classes of dry bean. Between 3 and 8 WAE, the level of injury was dependent on the bean market class and rate of sulfentrazone, and injury was highest at 4 WAE. Adzuki was the most sensitive, with sulfentrazone (140, 210, 280 and $420 \mathrm{~g} \cdot \mathrm{ai} \cdot \mathrm{ha} \mathrm{a}^{-1}$ ) causing up to $2 \%, 25 \%, 41 \%$, and $74 \%$ injury, respectively (Table 2). White bean experienced up to $4 \%, 13 \%, 33 \%$, and $57 \%$ injury at 140,210, 280 and $420 \mathrm{~g} \cdot \mathrm{ai} \cdot \mathrm{ha}^{-1}$, respectively. Kidney and small red Mexican were the most tolerant, with sulfentrazone causing $\leq 10 \%$ injury at rates below $280 \mathrm{~g} \cdot$ ai $\cdot \mathrm{ha}^{-1}$, while $420 \mathrm{~g} \cdot \mathrm{ai} \cdot \mathrm{ha}^{-1}$ caused up to $22 \%$

Table 2. Mean visible injury (\%) of four market classes of dry bean treated with sulfentrazone PRE at Ridgetown and Exeter, Ontario in 2014 and 2015. Means followed by the same letter in a row (X-Z) or column (a-d) for each rating are not significantly different according to Fisher's Protected LSD at $\mathrm{P}<0.05^{\text {a }}$.

\begin{tabular}{|c|c|c|c|c|c|c|c|c|c|c|c|c|}
\hline \multirow{3}{*}{$\begin{array}{c}\text { Sulfentrazone rate }\left(\mathrm{g} \cdot \mathrm{ai} \cdot \mathrm{ha}^{-1}\right) \\
\text { Injury } 3 \text { WAE } \\
0\end{array}$} & \multicolumn{3}{|c|}{ Adzuki Bean } & \multicolumn{3}{|c|}{ Kidney Bean } & \multicolumn{3}{|c|}{ Small Red Mexican Bean } & \multicolumn{3}{|c|}{ White Bean } \\
\hline & \multicolumn{12}{|c|}{$\%$} \\
\hline & 0 & $\mathrm{a}$ & & 0 & $\mathrm{a}$ & & 0 & a & & 0 & $\mathrm{a}$ & \\
\hline 140 & 2 & $\mathrm{~b}$ & Z & 2 & $\mathrm{~b}$ & $\mathrm{Z}$ & 2 & $\mathrm{~b}$ & $\mathrm{Z}$ & 4 & $\mathrm{~b}$ & Z \\
\hline 210 & 16 & $c$ & Z & 3 & $\mathrm{~b}$ & $\mathrm{Z}$ & 2 & $\mathrm{~b}$ & Z & 12 & $\mathrm{bc}$ & Z \\
\hline 280 & 35 & $\mathrm{~cd}$ & $\mathrm{Y}$ & 6 & $\mathrm{bc}$ & $\mathrm{Z}$ & 7 & $\mathrm{bc}$ & $\mathrm{Z}$ & 29 & $\mathrm{~cd}$ & $\mathrm{YZ}$ \\
\hline 420 & 64 & $\mathrm{~d}$ & $\mathrm{Y}$ & 22 & c & $\mathrm{Z}$ & 21 & c & $\mathrm{Z}$ & 54 & $\mathrm{~d}$ & $\mathrm{YZ}$ \\
\hline Injury 4 WAE & \multicolumn{12}{|c|}{$\%$} \\
\hline 0 & 0 & $\mathrm{a}$ & & 0 & $\mathrm{a}$ & & 0 & a & & 0 & a & \\
\hline 140 & 2 & $\mathrm{~b}$ & $\mathrm{Z}$ & 1 & $\mathrm{ab}$ & $\mathrm{Z}$ & 1 & $\mathrm{ab}$ & $\mathrm{Z}$ & 4 & $\mathrm{~b}$ & $\mathrm{Z}$ \\
\hline 210 & 25 & c & Z & 2 & $\mathrm{~b}$ & $\mathrm{Z}$ & 2 & $\mathrm{bc}$ & $\mathrm{Z}$ & 13 & $\mathrm{bc}$ & $\mathrm{Z}$ \\
\hline 280 & 41 & c & $\mathrm{x}$ & 5 & $\mathrm{bc}$ & $\mathrm{Z}$ & 6 & $\mathrm{bc}$ & $\mathrm{YZ}$ & 33 & $\mathrm{~cd}$ & $\mathrm{XY}$ \\
\hline 420 & 74 & $\mathrm{~d}$ & $\mathrm{Y}$ & 19 & c & $\mathrm{Z}$ & 15 & c & $\mathrm{Z}$ & 57 & $\mathrm{~d}$ & $\mathrm{Y}$ \\
\hline Injury 6 WAE & \multicolumn{12}{|c|}{$\%$} \\
\hline 0 & 0 & a & & 0 & a & & 0 & a & & 0 & a & \\
\hline 140 & 1 & $\mathrm{ab}$ & Z & 1 & $\mathrm{ab}$ & $\mathrm{Z}$ & 0 & $\mathrm{ab}$ & $\mathrm{Z}$ & 1 & $\mathrm{ab}$ & Z \\
\hline 210 & 8 & $\mathrm{bc}$ & Z & 1 & $\mathrm{ab}$ & Z & 1 & $\mathrm{~b}$ & Z & 2 & $\mathrm{bc}$ & Z \\
\hline 280 & 27 & $\mathrm{~cd}$ & $\mathrm{Y}$ & 2 & $\mathrm{~b}$ & Z & 3 & $\mathrm{~b}$ & $\mathrm{Z}$ & 10 & $\mathrm{~cd}$ & $\mathrm{YZ}$ \\
\hline 420 & 58 & $\mathrm{~d}$ & $\mathrm{X}$ & 6 & b & $\mathrm{YZ}$ & 5 & $\mathrm{~b}$ & $\mathrm{Z}$ & 33 & d & $\mathrm{XY}$ \\
\hline Injury 8 WAE & \multicolumn{12}{|c|}{$\%$} \\
\hline 0 & 0 & $\mathrm{a}$ & & 0 & $\mathrm{a}$ & & 0 & a & & 0 & $\mathrm{a}$ & \\
\hline 140 & 1 & $\mathrm{ab}$ & Z & 1 & $\mathrm{ab}$ & Z & 0 & $\mathrm{ab}$ & $\mathrm{Z}$ & 0 & $a b$ & $\mathrm{Z}$ \\
\hline 210 & 8 & $\mathrm{bc}$ & Z & 1 & $\mathrm{ab}$ & Z & 1 & $\mathrm{ab}$ & $\mathrm{Z}$ & 2 & $\mathrm{bc}$ & Z \\
\hline 280 & 17 & $\mathrm{~cd}$ & $\mathrm{Y}$ & 3 & $\mathrm{~b}$ & $\mathrm{YZ}$ & 2 & $\mathrm{~b}$ & $\mathrm{Z}$ & 5 & $\mathrm{bc}$ & $\mathrm{YZ}$ \\
\hline 420 & 49 & $\mathrm{~d}$ & $\mathrm{Y}$ & 5 & $\mathrm{~b}$ & Z & 2 & b & Z & 12 & c & $\mathrm{YZ}$ \\
\hline
\end{tabular}

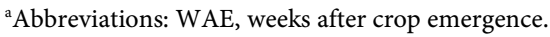


injury. Soltani et al. [10] also found kidney bean was more tolerant to sulfentrazone than white bean. In other studies examining PPO inhibitors on dry beans, flumioxazin applied PRE at $140 \mathrm{~g} \cdot \mathrm{ai} \cdot \mathrm{ha}^{-1}$ caused up to $34 \%$ injury in black, kidney, cranberry and white bean [12]. Fomesafen caused 5\% injury or less in black, cranberry, great northern, kidney, pink, pinto and white bean [13] [14]. Saflufenacil applied PRE at $50 \mathrm{~g} \cdot \mathrm{ai} \cdot \mathrm{ha}^{-1}$ caused up to $31 \%$ injury in adzuki, black, kidney and white bean [15] [16].

\subsection{Plant Density}

Small red Mexican bean and kidney bean densities were not reduced by any of the herbicide treatments compared to the control (Table 3). White bean had densities equivalent to the control at up to $280 \mathrm{~g} \cdot \mathrm{ai} \cdot \mathrm{ha}^{-1}$ of sulfentrazone. Sulfentrazone at $420 \mathrm{~g} \cdot \mathrm{ai} \cdot \mathrm{ha}^{-1}$ reduced white bean density by $28 \%$. Sulfentrazone at 140 and $210 \mathrm{~g} \cdot \mathrm{ai} \cdot \mathrm{ha}^{-1} \mathrm{did}$ not reduce adzuki bean density relative to the control, but sulfentrazone at 280 and 420 $\mathrm{g} \cdot \mathrm{ai} \cdot \mathrm{ha}^{-1}$ reduced density by $34 \%$ and $51 \%$, respectively. Soltani et al. [15] found saflufenacil applied PRE reduced plant density by $53 \%$ in black bean, $38 \%$ in kidney bean and $70 \%$ in white bean.

Table 3. Mean plant density, plant height, and yield as a percentage of the untreated control $\left(0 \mathrm{~g} \cdot \mathrm{ai} \cdot \mathrm{ha}^{-1}\right)$ of four market classes of dry bean treated with sulfentrazone PRE at Ridgetown and Exeter, Ontario in 2014 and 2015. Means followed by the same letter in a row (X-Z) or column (a-d) for each variable are not significantly different according to Fisher's Protected LSD at $\mathrm{P}<0.05$.

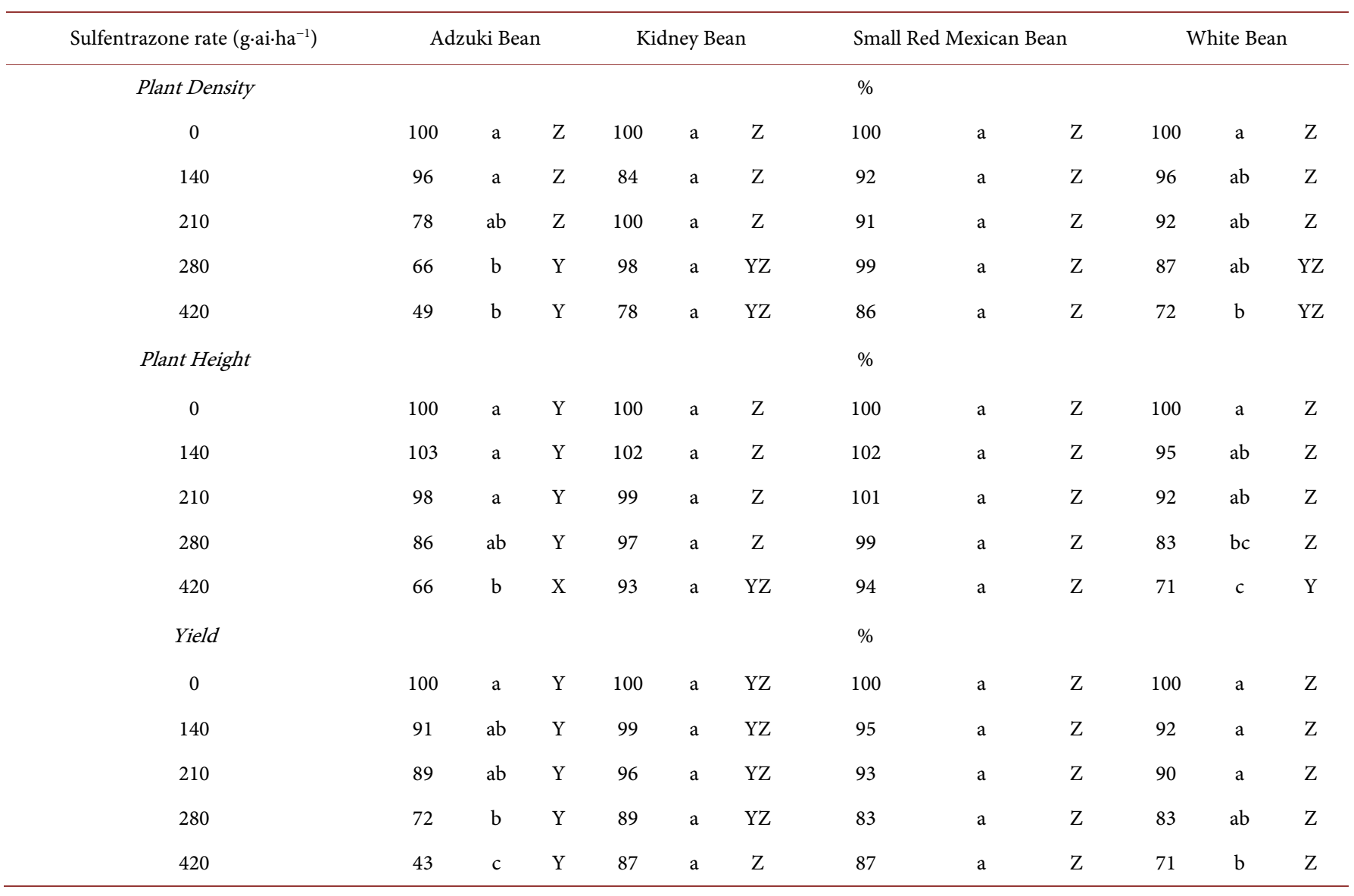




\subsection{Shoot Dry Weight}

Shoot dry weight was not affected by sulfentrazone at 140 or $210 \mathrm{~g} \cdot \mathrm{ai} \cdot \mathrm{ha}^{-1}$ (Table 1 ). Shoot dry weight was reduced by $11 \%$ at $280 \mathrm{~g} \cdot \mathrm{ai} \cdot \mathrm{ha}^{-1}$ and $28 \%$ at $420 \mathrm{~g} \cdot \mathrm{ai} \cdot \mathrm{ha} \mathrm{a}^{-1}$. In contrast, Hekmat et al. [11] did not observe a decrease in dry bean shoot dry weight when treated with $420 \mathrm{~g} \cdot \mathrm{ai} \cdot \mathrm{ha}^{-1}$ of sulfentrazone. Flumioxazin applied PRE reduced shoot dry weight for black and white bean, but not for cranberry or kidney bean [12]. Saflufenacil reduced black and white bean shoot dry weight by up to $41 \%$, but did not reduce adzuki or kidney bean shoot dry weight [15].

\subsection{Plant Height}

Shorter plant heights can cause reduced yield at harvest due to harvest losses at the cutter bar of the combine. Kidney bean and small red Mexican bean height were not reduced by any of the sulfentrazone rates evaluated (Table 3). Adzuki bean height was reduced at $420 \mathrm{~g} \cdot \mathrm{ai} \cdot \mathrm{ha}^{-1}$ by $34 \%$, while white bean height was reduced by $17 \%$ at 280 g.ai $\cdot \mathrm{ha}^{-1}$ and $29 \%$ at $420 \mathrm{~g} \cdot \mathrm{ai} \cdot \mathrm{ha}^{-1}$. These results both agree and conflict with a study by Hekmat et al. [11]. In Hekmat et al. [11], sulfentrazone at $420 \mathrm{~g} \cdot \mathrm{ai} \cdot \mathrm{ha}^{-1}$ also did not reduce kidney bean height, but white bean (“OAC Thunder") height was equivalent to the control, which may indicate some differential cultivar sensitivity to sulfentrazone. In other studies, saflufenacil did not reduce adzuki or kidney bean height [15]. Flumioxazin did not reduce cranberry or kidney bean height relative to the control, but black bean height was reduced by $24 \%$ and white bean height was reduced by $29 \%$ [12].

\subsection{Seed Moisture Content and Yield}

Herbicide injury can cause delayed maturity of the crop which can cause seed damage from delayed harvest and storage problems. Delayed maturity is indicated by elevated seed moisture content. In this study, sulfentrazone at 140, 210 and $280 \mathrm{~g} \cdot \mathrm{ai} \cdot \mathrm{ha}^{-1}$ did not increase seed moisture content compared to the untreated control, but seed moisture was $1.2 \%$ higher for the beans treated with $420 \mathrm{~g} \cdot \mathrm{ai}^{\mathrm{h}} \mathrm{ha}^{-1}$ (Table 1). Kidney bean and small red Mexican bean yields were not significantly reduced by any of the rates evaluated (Table 3). Adzuki bean yield was not affected by sulfentrazone at 140 and 210 g.ai.ha ${ }^{-1}$, yielding $91 \%$ and $89 \%$ of the control, respectively. In contrast, sulfentrazone at $280 \mathrm{~g} \cdot \mathrm{a} \cdot \mathrm{ha}^{-1}$ reduced adzuki yield by $28 \%$ and $420 \mathrm{~g} \cdot \mathrm{ai} \cdot \mathrm{ha}^{-1}$ reduced yield by $57 \%$. Soltani et al. [1] found saflufenacil reduced adzuki bean yield by $56 \%$. White bean yield was not reduced compared to the control by rates up to $280 \mathrm{~g} \cdot \mathrm{a} \cdot \mathrm{h} \mathrm{h}^{-1}$, but was reduced by $29 \%$ at $420 \mathrm{~g} \cdot a \mathrm{i} \cdot \mathrm{ha} \mathrm{a}^{-1}$. In contrast, Hekmat et al. [11] found white bean yield was equivalent to the untreated control but was numerically reduced by $17 \%$ by sulfentrazone (420 g.ai $\left.\cdot \mathrm{ha}^{-1}\right)$. This difference could be attributed to a different cultivar used in that study. Soltani et al. (2014a) did not find a decrease in yield in black, cranberry, kidney or white bean treated with sulfentrazone at rates up to $280 \mathrm{~g} \cdot \mathrm{ai} \cdot \mathrm{ha}^{-1}$.

\section{Conclusion}

In this study, kidney bean and small red Mexican bean demonstrated the highest toler- 
ance to PRE applications of sulfentrazone; plant density, height, and yield were not affected at any of the rates evaluated, and there was an acceptable margin of crop safety for rates up to $280 \mathrm{~g} \cdot \mathrm{ai} \cdot \mathrm{ha}^{-1}$. White bean had the next best tolerance, with plant density and yield only affected at $420 \mathrm{~g} \cdot \mathrm{ai} \cdot \mathrm{ha}^{-1}$, and a narrow margin of crop safety at rates up to $210 \mathrm{~g} \cdot \mathrm{a} \cdot \mathrm{ha}^{-1}$. Adzuki bean had the poorest tolerance of the market classes evaluated, with plant density and yield reduced by 280 and $420 \mathrm{~g} \cdot a \mathrm{i} \cdot \mathrm{ha}^{-1}$, and unacceptable injury at $210 \mathrm{~g} \cdot \mathrm{ai} \cdot \mathrm{ha}^{-1}$ and above. Based on these results, PRE applications of sulfentrazone are safe for kidney and small red Mexican bean production in Ontario.

\section{References}

[1] Kulasekera, K. (2015) Estimated Area, Yield, Production and Farm Value of Specified Field Crops, Ontario, 2011-2015. Ontario Ministry of Agriculture, Food and Rural Affairs. http://www.omafra.gov.on.ca/english/stats/crops/estimate_new

[2] Woolley, B.I., Michaels, T.E., Hall, M.R. and Swanton, C.J. (1993) The Critical Period of Weed Control in White Bean (Phaseolus vulgaris). Weed Science, 41, 180-184.

[3] Ghamari, H. and Ahmadvand, G. (2012) Weed Interference Affects Dry Bean Yield and Growth. Notulae Scientia Biologicae, 4, 70-75.

[4] Hadi, H., Ghassemi-Golezani, K., Khoei, F.R., Valizadeh, M. and Shakiba, M.R. (2006) Response of Common Bean (Phaseolus vulgaris) to Different Levels of Shade. Journal of Agronomy, 5, 595-599. http://dx.doi.org/10.3923/ja.2006.595.599

[5] Malik, V.S., Swanton, C.J. and Michaels, T.E. (1993) Interaction of White Bean (Phaseolus vulgaris) Cultivars, Row Spacing, and Seeding Density with Annual Weeds. Weed Science, 41, 62-68.

[6] Heap, I. (2016) The International Survey of Herbicide Resistant Weeds. http://weedscience.org/summary/country.aspx

[7] Niekamp, J.W., Johnson, W.G. and Smeda, R.J. (1999) Broadleaf Weed Control with Sulfentrazone and Flumioxazin in No-Tillage Soybean (Glycine max). Weed Technology, 13, 233-238.

[8] Niekamp, J.W. and Johnson, W.G. (2001) Weed Management with Sulfentrazone and Flumioxazin in No-Tillage Soyabean (Glycine max). Crop Protection, 20, 215-220. http://dx.doi.org/10.1016/S0261-2194(00)00129-0

[9] Anonymous (2012) Authority 480 Herbicide. FMC Corporation, 4 p.

[10] Soltani, N., Shropshire, C. and Sikkema, P.H. (2014) Response of Dry Bean to Sulfentrazone plus Imazethapyr. International Journal of Agronomy, 2014, Article ID: 287908. http://dx.doi.org/10.1155/2014/287908

[11] Hekmat, S., Shropshire, C., Soltani, N. and Sikkema, P.H. (2007) Responses of Dry Beans (Phaseolus vulgaris L.) to Sulfentrazone. Crop Protection, 26, 525-529. http://dx.doi.org/10.1016/j.cropro.2006.05.002

[12] Soltani, N., Bowley, S. and Sikkema, P.H. (2005) Responses of Dry Beans to Flumioxazin. Weed Technology, 19, 351-358. http://dx.doi.org/10.1614/WT-04-146R1

[13] Wilson, R.G. (2005) Response of Dry Bean and Weeds to Fomesafen and Fomesafen Tank Mixtures. Weed Technology, 19, 201-206. http://dx.doi.org/10.1614/WT-04-166R

[14] Sikkema, P.H., Shropshire, C. and Soltani, N. (2009) Response of Dry Bean to Pre-Plant Incorporated and Pre-Emergence Applications of S-Metolachlor and Fomesafen. Crop Protection, 28, 744-748. 
[15] Soltani, N., Shropshire, C. and Sikkema, P.H. (2014) Sensitivity of Dry Bean to Dimethenamid-p, Saflufenacil and Dimethenamid-p/Saflufenacil. American Journal of Plant Sciences, 5, 3288-3294. http://dx.doi.org/10.4236/ajps.2014.521343

[16] Soltani, N., Shropshire, C. and Sikkema, P.H. (2010) Sensitivity of Leguminous Crops to Saflufenacil. Weed Technology, 24, 143-146. http://dx.doi.org/10.1614/WT-09-029.1

Submit or recommend next manuscript to SCIRP and we will provide best service for you:

Accepting pre-submission inquiries through Email, Facebook, LinkedIn, Twitter, etc. A wide selection of journals (inclusive of 9 subjects, more than 200 journals)

Providing 24-hour high-quality service

User-friendly online submission system

Fair and swift peer-review system

Efficient typesetting and proofreading procedure

Display of the result of downloads and visits, as well as the number of cited articles

Maximum dissemination of your research work

Submit your manuscript at: http://papersubmission.scirp.org/

Or contact ajps@scirp.org 